\title{
The Uruguay Round Agreement on Agriculture: A New Order?
}

\author{
Donald MacLaren
}

7 The negotiations on agricultural policies played an important role in the Uruguay Round of the GATT, agreement on which was signed at Marrakesh in April 1994. The six years taken to reach agreement on agriculture reflected both the political sensitivity and the technical complexity of the agenda. The Agreement on Agriculture that is part of the new GATT within the World Trade Organisation (WTO) is to be implemented in July 1995.

The Agreement will not deliver agricultural trade liberalisation in the short to medium term as many had hoped and as seemed possible when the Draft Final Act was published in December 1991. Instead, the Agreement has produced a new set of operational rules for domestic agricultural and agricultural trade policies. The long-standing device of bindings used in the GATT - that tariff rates, once agreed, cannot be increased without compensation to the contracting parties - has been extended for agricultural policies to levels of domestic transfers and to export subsidies, as well as to import tariffs. This innovation represents a fundamental breakthrough because, given the dismal history of agricultural negotiations in previous GATT Rounds, it was necessary to change the rules if long-lasting trade liberalisation was to be achieved. The monitoring of adherence to these new rules by the Committee on Agriculture in the WTO, together with improved dispute settlement procedures, should ensure that governments are able to resist more resolutely the demands for higher income support from their farm lobbies and that, eventually, international trade in agricultural products will reflect comparative advantage rather than domestic agricultural policies and budgetary expenditures on these policies. Traditionally, economists, using the tools of applied welfare economics, have viewed government as an omniscient planner, aloof from the influence of farm lobby groups. In reality, governments in the developed countries have largely been captured by these lobbies and, therefore, are not independent in the policy decisions taken.

\section{Background}

It is often said that international trade in agricultural products has remained outside the GATT system. To the extent that this has been true, it has stemmed from an

Donald MacLaren is Associate Professor in the Department of Economics at the University of Melbourne. 
unresolved ambivalence on the part of the contracting parties about the economic status of the agricultural sector. At one extreme, some governments have advocated a neoclassical economic stance; at the other, some have argued that agriculture has a special economic and social status requiring a special set of rules. Among the major players, the United States has consistently advocated (though not in practice adopted) the former stance for exported products but the latter for importcompeting products. The European Union (EU) and Japan have at least been consistent advocates of the interventionist position. ${ }^{1}$

Yet the view that agriculture has remained outside the GATT system is not wholly true. The Articles of GATT include special provisions for agriculture; Articles XI and XVI refer respectively to quantitative import restrictions and to export subsidies. These provisions exist in recognition of the fact that economic efficiency is but one of governments' legitimate objectives for agriculture, and perhaps even a minor objective. Industrialised countries' other (not necessarily mutually consistent) objectives have included higher and more stable incomes for farm families, the conservation of the social fabric of rural areas, the modernisation of the sector, the provision of food security, and protection of the domestic sector from the alleged vagaries of international markets. To these traditional objectives should now be added the preservation of the rural environment.

Since the GATT was established in 1947, governments have been unwilling and, in many instances, politically unable to control their pursuit of these domestic objectives so as to create a more open and efficient international trading system for agricultural products. Agricultural protectionism has therefore been widely regarded as an intractable problem. However, the tide began to turn in 1982 when the Ministerial Trade Mandate was established in the OECD. It required estimates to be made of the assistance given to agriculture in OECD countries and of the effects of reducing that assistance. Assistance was estimated by use of an aggregate measure of support based on subsidy equivalents, a measure which, in the Agreement on Agriculture, was later to form the basis of the reductions in the support provided by domestic agricultural policies.

This change of attitude was strengthened at the start of the Uruguay Round in 1986, which acknowledged the need to liberalise agricultural policies through 'improving the competitive environment by increasing discipline on the use of direct and indirect subsidies and other measures affecting directly or indirectly agricultural trade, including the phased reduction of their negative effects and dealing with their causes' (GATT, 1986:12). The six sets of country or country-group proposals submitted to the Negotiating Group on Agriculture in 1987 and 1988 ranged from the neoclassical but politically infeasible proposals of the US, such as eliminating all trade-distorting policies over a ten-year period, to the more cautious and protectionist proposals of the EC. The proposals of the Cairns Group of commodity-

\footnotetext{
1 The name 'European Community' (EC) is used for the period before November 1993, and 'European Union' (EU) thereafter, to reflect the change of name following implementation of the Maastricht Treaty.
} 
exporting countries were closer to the US position, whereas the Japanese proposals were closer to those of the EC. ${ }^{2}$

The subsequent lack of agreement within the Negotiating Group caused the Montreal Mid-Term Review to fail. Thereafter, in 1989 the US and the EC shifted from confrontation towards cooperation. The US proposed a rules-based approach that included the tariffication of all non-tariff barriers, the banning of export subsidies and the classification of domestic policy instruments into 'trade distorting' and 'minimally trade distorting' categories. The Cairns Group agreed, but the EC did not; and the planned final meeting of the Round in Brussels in 1990 failed. However, in early 1991 the EC published proposals to reform its Common Agricultural Policy that indicated that the EC was moving towards its trading partners. This made it possible for an agricultural package to be proposed as part of the Draft Final Act in December 1991 based on market access, domestic support and export competition. Some aspects were unacceptable to the EC; and the outcome of bilateral discussions with the US, held in November 1992 at Blair House, weakened in crucial respects elements of the Draft Final Act (such as reductions in domestic support to apply to the agricultural sector in aggregate rather than on an individual commodity basis). The Draft Final Act was further weakened at the final meeting of the Uruguay Round negotiators in December 1993. Nevertheless, the changes in agricultural and trade policies that come into effect in July 1995, though falling far short of the original US and Cairns Group proposals, amount to a major improvement on the outcomes for agriculture of previous rounds of GATT negotiations.

\section{The Agreement on Agriculture}

The Agreement ${ }^{3}$ consists of two parts, dealing respectively with the new rules and with the country-specific schedules of commitments towards liberalisation. The principal elements of the first part fall under the headings of market access, domestic support and export competition. Contracting parties are divided into developed and developing countries; the latter are given a longer time period for adjustment and smaller required percentage reductions in protection and assistance.

New rules. Under the heading of market access, all import barriers will be converted to tariffs and then, for the developed countries, the unweighted average of these tariffs will be reduced by 36 per cent from the $1986-88$ base period over six years beginning in July $1995 .^{4}$ For any one tariff line, the minimum reduction is 15 per cent. To ensure some improvement in market access where non-tariff barriers have been converted to tariffs, minimum-access provisions of 3 per cent have also been agreed, rising to 5 per cent of domestic consumption. These provisions will

\footnotetext{
${ }^{2}$ A summary of the six sets of proposals may be found in Rossmiller (1988).

${ }^{3}$ Further details of the material in this section can be found in International Agricultural Trade Research Consortium (IATRC) (1994) and Hathaway and Ingco (1995).

4 For Japan and Korea, a period of grace was granted so that tarification of barriers to rice imports will not occur until 2001.
} 
be implemented by means of tariff-rate quotas. In case of import surges caused by market forces and exchange rate variations, protection may be increased under a Special Safeguard Provision based on either a quantity or a price trigger. By the end of the implementation period, all agricultural tariff rates in the developed countries will be bound.

Domestic support measures will be a classified as 'amber box' policies (which distort production or trade) or as 'green box' policies (which do not, or do so only minimally). Amber box policies are part of the aggregate measure of support calculation and are subject to a reduction of 20 per cent from the 1986-88 base period. The partially decoupled income support provided in the US by deficiency payments programs and in the EU by compensatory payments associated with land set-asides are exempt from the 20 per cent reduction, having been put in a 'blue box' as a result of the Blair House bilateral agreement. ${ }^{5}$

From 1995, export subsidies are to be reduced by 21 per cent measured in export volume and by 36 per cent measured in export value relative to the base period of 1986-90. No country may introduce an export subsidy for any product that was not subsidised in the base period. However, new countries can be added to the list of those already the target of subsidised exports. ${ }^{6}$ In addition, a so-called 'Peace Clause' is designed to safeguard all policies that conform to the new rules from being challenged through the dispute-settlement procedures.

Country-specific schedules. The second part of the Agreement contains the country-specific new tariff rates and tariff-rate quotas, information on reductions in domestic support and the schedule of reductions in export subsidies. Careful study of these details has led some analysts to conclude that very little trade liberalisation will occur, because of the way in which counties have chosen to implement the Agreement. As the 36 per cent reduction in tariff rates is an unweighted average, governments were always likely to continue to protect the politically sensitive products to the greatest extent possible by maximising the percentage reductions on the politically insensitive products. For example, Hathaway and Ingco (1995), who compared the country schedules against actual average tariff rates for the decade 198292 , found that improvements in market access were almost non-existent among the OECD countries for most products, particularly sugar, meats and dairy products. In addition, because the base period chosen was one of unusually low world prices, the tariff rates implicit in the non-tariff barriers were unusually high. This provides scope to maintain excessive protection in more normal times even after the agreed reductions in tariff rates. Moreover, many countries undertook 'dirty tariffication'

\footnotetext{
${ }^{5}$ Decoupled income-support measures transfer income without affecting prices, production, consumption, and hence trade: that is, there is no link between the size of the income support and the level of output.

${ }^{6}$ The recent addition of eleven Asian countries to the list of those that receive subsidised exports of dairy products from the US through its Dairy Export Incentive Program illustrates the difficulty for small exporting countries such as Australia, which will be harmed by this GATT-legal move.
} 
of non-tariff barriers by using creative arithmetic to arrive at higher tariff rates for the base period than those that would have been determined by more honest means. However, market access will also be affected by the minimum access commitments, which will to some extent offset the effects of 'dirty tariffication'. Finally, on market access, the Agreement failed to mention the role of state trading agencies, in particular their effect on price transmission from international to domestic markets (with state trading agencies as monopoly importers, there is no guarantee that reduced tariffs will cause lower consumer prices and increased consumption and imports).

In the Agreement, the reduction of domestic support from policy instruments classified as amber box policies applies to the entire output of the agricultural sector. In the Draft Final Act, the 20 per cent reduction was to apply to each and every commodity. At Blair House, the US and the EC agreed bilaterally to apply the reduction to the sector aggregate and then to exempt their own partially decoupled support mechanisms. These changes substantially weakened the quantitative effect of this component of the Agreement, because, once again, it allowed governments to continue to protect the already over-protected sensitive products. It would be possible for governments to maintain existing levels of support but to reduce that support from amber box policies by 're-instrumentation', that is, by increasing the use of green box policies. However, it is unlikely that this course of action will be significant, because of the resistance of the farm lobby to transparent incometransfer mechanisms.

The effect of the restrictions on export subsidies will differ from country to country and from product to product. For example, Hathaway and Ingco (1995) indicate that the volume constraint will be the more binding for the EU, whereas the expenditure constraint will be the more binding for the US. For Australia, there will be a re-instrumentation for dairy products to remove the current export subsidy and to provide assistance at previously agreed levels by a GATT-consistent mechanism. Again, the Agreement did not address the issue of state-sponsored export monopolies, such as the Australian and Canadian Wheat Boards, and the possibility of their creating international price distortions through price discrimination in a differentiated product.

The overall quantitative effects of the Agreement on Agriculture are less spectacular than even the modest effects calculated earlier from several models in which the effects of the original Draft Final Act proposals were simulated. However, given the degree of dirty tariffication, the uncertainty over which products will be subject to only minimum cuts in tariff rates, and which products will remain heavily supported by domestic instruments rather than being cut by 20 per cent, it is impossible to run the true simulation experiment using any computable general equilibrium model. ${ }^{7}$

\footnotetext{
${ }^{7}$ Francois et al. (1995) provide a comprehensive review of the modelling issues as well as a range of results.
} 


\section{The SPS Agreement}

The Sanitary and Phytosanitary (SPS) Agreement was separate from the Agreement on Agriculture. It is important to note that this Agreement covers only those scientifically based measures related to human, plant and animal health: it does not deal with the increasingly debated issues of consumer concerns, animal welfare and environmental matters to do with food and agriculture.

What the Agreement does do is establish guidelines for government behaviour by improving the operation of Article XX through helping to distinguish between standards based on genuine health and safety issues and those used as disguised technical barriers to trade. The SPS Agreement will operate in three ways. First, countries may continue to use their own domestic standards; but these have to be based on sound scientific evidence, should not discriminate between countries and must be subject to risk assessment. Second, countries may harmonise their own standards with those standards specified by the relevant international institution, such as the Codex Alimentarius Commission. Third, countries may use the concept of equivalence to maintain different but acceptable equivalent standards. Despite these improvements, plenty of scope remains for disputes to arise, for example, because scientific evidence is rarely totally unambiguous and risk assessments may differ (see Hillman, 1994:222-4, for more detail). A WTO Committee on SPS measures is therefore to be established.

\section{Other Agreements Affecting Agriculture}

GATT's dispute-settlement procedures (under Article XXIII) have so far been ineffective in disputes over agriculture, in particular those involving complaints about the use of export subsidies. There have been major difficulties. First, governments have had the ability to block or at least delay the implementation of a panel ruling that has found against their particular policy interventions. Second, panels have had to determine whether or not more than an 'equitable market share' has been gained through the subsidising of exports. In many instances, panels have been unable to make a judgment because they found it difficult to ascertain the trade flows that would have existed in the absence of the export subsidy.

The new dispute-settlement procedure (called the Understanding on Rules and Procedures Governing the Settlement of Disputes) improves the position for agriculture by introducing a binding appeals procedure. A panel report will be deemed accepted by the Council unless the ruling is appealed by one of the Contracting Parties. If appealed, the matter goes to an appellant body which then reports to the Council; this finding is then adopted unless there is a consensus against adoption. The presumption of the previous procedure has thus been reversed and, moreover, will carry the weight of international law. This reversal should benefit small countries that initiate the establishment of panels. Refusal by a country to abide by a ruling invites a request for compensation or else the initiation of retaliatory action. Jackson (1994:120) notes that as there is no stare decisis rule in international law, a panel ruling need not set a precedent, although there is a tendency for it to do so. 
Hudec (1994), while supporting the new dispute settlement procedures, believes that the GATT/WTO does not have the resources necessary to implement the new system successfully. This is a serious point, given the importance of these procedures to resolving international trade tensions in agriculture.

Two other Agreements from the Uruguay Round have more importance for international trade in processed agricultural products than for basic agricultural commodities. In the Subsidies and Countervailing Measures Agreement, subsidies are put into one of three categories: 'prohibited' (like export and domestic subsidies), 'actionable' (such as those that adversely affect a sector in another country) and 'non-actionable' (such as subsidies for research or for regional development). ${ }^{8}$ Countervailing measures are permitted only against prohibited or actionable subsidies, and redress can be sought through the dispute-settlement procedures. ${ }^{9}$ As for the Anti-Dumping Agreement (Agreement on the Implementation of Article VI), Finger (1994:105) is critical of its wording, especially its avoidance of a definition of 'dumping', and believes that this Agreement will not be as effective as the Agreement on Subsidies and Countervailing Measures.

\section{Unfinished Agenda}

The Agreement on Agriculture commits governments to a process of staged adjustments in import protection, domestic support and export assistance. Together with the SPS Agreement and the new dispute-settlement agreement, the Agreement will eventually lead to less distorted agricultural trade, reduced international tensions, a more easily interpreted set of rules and more enforceable decisions. However, no matter how different this outcome is from the outcomes of previous Rounds, it is really only a first step in what must be a continuing process of negotiated reforms of agricultural policies. In the short and medium terms, the quantitative effects on domestic and trade policies will be small; further steps will therefore be required to achieve effective reductions in agricultural protectionism. To that end, it was agreed that a review and further negotiation would take place in 1999, one year before the end of the implementation period.

The principal elements of the unfinished agenda arise largely, but not totally, from the second part of the Agreement on Agriculture. First, because many of the new, bound tariff rates will remain at prohibitive levels even after the agreed reductions, more realistic reductions will need to be negotiated if more substantial market access is to be achieved. Second, as a consequence of meeting the unweighted average tariff-rate reductions, the dispersion of tariff rates will increase over those in the base period. An attempt must therefore be made to cut the highest rates first, that is, to use the Swiss formula approach that was used for manufactures in the Tokyo Round 1973-79.

\footnotetext{
${ }^{8}$ For basic agricultural commodities, in the sense used in GATT Article XVI:3, export subsidies will continue to be permitted within the rules defined under export competition in the Agreement on Agriculture as discussed above.

${ }^{9}$ See Baldwin (1992) for an economic analysis of this categorisation.
} 
Third, the mutual generosity that the US and the EU displayed at Blair House in exempting the bulk of their domestic-support programs from the discipline of the 20 per cent reduction must be altered to bring these partially decoupled payments within the amber box. Whether this beneficial outcome will be attained easily depends in part on the outcome of the 1995 US Farm Bill (see Roberts and Andrews, 1995). At present, there is considerable tension in Congress between those who want to make radical changes to farm programs and those who are prepared to accept only marginal adjustments. In addition, an evaluation of the reforms of the EU's Common Agricultural Policy that were implemented in 1993 will be undertaken in 1996. As in the US, considerable tension exists between those who wish to turn the clock back and those who wish to see the process of reform taken further. Again, the mood for the 1999 mini-round will be determined partly by what happens in Brussels in 1996.

Fourth, it is important that the dispersion in the levels of domestic support is removed by returning to the original Draft Final Act proposals of applying reductions in the aggregate measure of support to each commodity rather than their aggregate. This outcome would reduce the price and trade distortions caused by excessive support for politically sensitive commodities like sugar and dairy products.

Fifth, depending on what happens in the US in 1995 and the EU in 1996, there is the danger that increased use will be made of supply management programs in order to meet export subsidy constraints. From an economic perspective, it would be preferable instead to lower product prices in order to reduce the distortions created by land set-aside schemes.

Sixth, the minimum market-access provisions provided through tariff-rate quotas have two undesirable consequences. They will be difficult and costly for the WTO Committee on Agriculture to monitor because they are applied to each tariff line; and they will generate quota rents and so introduce inefficiencies and an additional source of pressure from political lobbies. However, these provisions will also bring benefits: by reducing the price-insulating effects of existing non-tariff barriers, thereby reducing the gap between domestic and international prices and the consequential deadweight losses; and by providing greater incentives among exports to compete for a share of the import market.

Seventh, it became apparent over the years of the Uruguay Round negotiations that the relationships between trade and the environment were becoming of increasing concern. The position has been stated succinctly by Hathaway (1994:169):

It is clear that the world is moving to new issues for the next trade negotiations. Environment tops the list and neither environmentalists [n]or agriculturalists appear to recognise that agriculture will inevitably be in the centre of trade and environment negotiations.

And eighth, if the nexus of agricultural and environmental issues is truly important, then the concept of the 1999 mini-round, as a single-sector round, may be a poor one because there will be no opportunity for countries to trade off gains and 
losses in different sectors in order to achieve an acceptable multilateral outcome. One lesson from the Uruguay Round is that having a number of groups negotiating concurrently made it possible to make more transparent the benefits forgone in non-agricultural areas if the negotiations on agriculture were allowed to fail. ${ }^{10}$ But such a strategy may not work again. Given the belief among politicians (though not in Australia) that the Uruguay Round reformed agriculture to such a degree that further reforms are not a pressing need, they are not going to take the risk of forgoing major benefits in other areas by making them contingent upon further reforms in agriculture (Hathaway, 1994). If Hathaway's scepticism is correct, then the outcomes of the mini-round of 1999 desired by economists may prove every bit as difficult to achieve as was the Agreement on Agriculture.

\section{Conclusion}

When viewed in the light of the history of agriculture in the GATT, the Agreement on Agriculture is both innovative and successful. It is innovative because the concept of bindings is now to be extended to domestic support and export subsidies as well as import tariffs. The Agreement is successful qualitatively because non-tariff barriers are to be converted to tariff barriers and bound. In addition, there is to be a phased reduction in tariff rates, in the more trade-distorting forms of domestic support and in export subsidies. It was also accepted that domestic agricultural policies are the principal cause of distorted international markets; and it was crucial that, for the first time in the GATT, they were the subject of negotiation. In conjunction with the SPS agreement and the new dispute-settlement agreement, agricultural policies and international trade should be of less concern in the future than they were during the GATT 1947 era.

However, much remains to be done to tidy up the old agenda. For example, the discussions in 1999 need to focus on substantial quantitative reductions in agricultural protectionism which go beyond defining the rules, a task that was successfully achieved by 1993 in the Final Act. If developed country governments continue to recognise that markets do have a greater role, and budgets and consumer transfers a smaller role, in the economic well-being of the farm sector, then the outlook for progress in 1999 is bright. But there is no guarantee that such a trend will continue. On the other hand, greater government involvement and cooperation will be needed if trade and the environment are to head the list of new issues for international trade negotiations.

Agricultural protectionism has been capped but by no means significantly reduced. However, there are hopeful signs that the growing disenchantment apparent among many developed country governments with the mechanisms that they have used to achieve their policy objectives for agriculture will be translated into a substantial decrease in agricultural protectionism over the next decade. The Uruguay

\footnotetext{
${ }^{10}$ This strategy was used effectively by the Cairns Group at Montreal in 1988 when it refused to accept progress in other negotiating groups until the agriculture negotiations were successful.
} 
Round Agreement on Agriculture does mark the beginning of a new era for agricultural policies and international trade.

\section{References}

Baldwin, R. (1992), 'Assessing the Fair Trade and Safeguards Laws in Terms of Modern Trade and Political Economy Analysis', The World Economy 15: 185-202.

Finger, M. (1994), 'Subsidies and Countervailing Measures and Anti-Dumping Agreements', Ch. 9 in OECD Documents: The New World Trading System-Readings, Paris.

Francois, J., B. McDonald \& H. Nordström (1995), 'Assessing the Uruguay Round', a paper presented at The Uruguay Round and the Developing Economies, A World Bank Conference, 26-27 January, Washington DC.

GATT (1986), Draft Ministerial Declaration on the Uruguay Round, MIN (86) / W / 19, 20 September.

Hathaway, D. (1994), 'New World Order in Agricultural Trade', Ch. 18 in OECD Documents: The New World Trading System - Readings, Paris.

— \& M. Ingco (1995), 'Agricultural Liberalization and the Uruguay Round', a paper presented at The Uruguay Round and the Developing Economies, A World Bank Conference, 26-27 January, Washington DC.

Hillman, J. (1994), 'The Uruguay Round: From Cold War to Cooperation in Negotiating Temperatezone Agricultural and Trade Policies', Review of Marketing and Agricultural Economics 62(2): 215-30.

Hudec, R. (1994), 'Dispute Settlement', Ch. 14 in OECD Documents: The New World Trading Sys. tem-Readings, Paris.

IATRC (1994), The Uruguay Round Agreement on Agriculture: An Evaluation, University of Minnesota (Commissioned Paper No. 9).

Jackson, J. (1994), 'Dispute Settlement Procedures', Ch. 11 in OECD Documents: The New World Trading System - Readings, Paris.

Roberts, I. \& N. Andrews (1995), 1995 US Farm Bill: A Tuming Point?, ABARE, Canberra (Research Report 95.2).

Rossmiller, E. (1988), 'Agricultural Proposals in the GATT', Choices, Second Quarter: 30-1.

The helpful comments of two referees are gratefully acknowledged. 